\title{
Mapping the Emergence of International University Research Ventures
}

DOI:

10.1007/s10961-017-9640-6

\section{Document Version}

Accepted author manuscript

Link to publication record in Manchester Research Explorer

\section{Citation for published version (APA):}

Kolesnikov, S., Woo, S., Li, Y., Shapira, P., \& Youtie, J. (2017). Mapping the Emergence of International University Research Ventures. Journal of Technology Transfer. https://doi.org/10.1007/s10961-017-9640-6

\section{Published in:}

Journal of Technology Transfer

\section{Citing this paper}

Please note that where the full-text provided on Manchester Research Explorer is the Author Accepted Manuscript or Proof version this may differ from the final Published version. If citing, it is advised that you check and use the publisher's definitive version.

\section{General rights}

Copyright and moral rights for the publications made accessible in the Research Explorer are retained by the authors and/or other copyright owners and it is a condition of accessing publications that users recognise and abide by the legal requirements associated with these rights.

\section{Takedown policy}

If you believe that this document breaches copyright please refer to the University of Manchester's Takedown Procedures [http://man.ac.uk/04Y6Bo] or contact uml.scholarlycommunications@manchester.ac.uk providing relevant details, so we can investigate your claim.

\section{OPEN ACCESS}




\title{
Mapping the Emergence of International University Research Ventures
}

\author{
Sergey Kolesnikov ${ }^{1, *}$, Seokkyun $\mathrm{Woo}^{2}$, Yin $\mathrm{Li}^{2}$, Philip Shapira ${ }^{2,4}$, Jan Youtie ${ }^{3}$
}

1. Center for Organization Research and Design, Arizona State University, Phoenix, AZ 85004-3720, USA

2. School of Public Policy, Georgia Institute of Technology, Atlanta, GA 30332-0345, USA

3. Enterprise Innovation Institute, Georgia Institute of Technology, Atlanta, GA 30308, USA

4. Manchester Institute of Innovation Research, Alliance Manchester Business School, University of Manchester, Manchester M13 9SS, UK

* Corresponding author: skolesnikov01@gmail.com

November 2017

Forthcoming in the Journal of Technology Transfer

Author Accepted Manuscript 


\title{
Mapping the Emergence of International University Research Ventures
}

\begin{abstract}
Research universities are expanding their institutional research presence overseas through the creation of research centers, facilities and partnerships outside of their home countries. We argue that such international university research ventures (IURV) are a distinct type of intermediary node in global knowledge networks occurring at the intersection of three trends: (1) expanding international research collaborations, (2) globalization of higher education, and (3) growing demand for capacity building in science, technology and innovation in emerging economies. To understand and characterize the scope and scale of this phenomenon we undertake an exploratory study of IURVs of 108 researchintensive universities in the United States. Data on U.S. IURV locations and their characteristics is collected from university websites and other secondary sources. We find that 54 US research universities have established at least one IURV, with 183 IURVs in total created in 59 countries. A conceptual framework based on motivations and pathways of IURV emergence is developed. It distinguishes between strategy-driven, collaboration-driven, policydriven and problem-driven IURVs. Insights from the mapping of US IURVs are discussed, along with implications for future research.
\end{abstract}

Keywords: university internationalization; globalization of R\&D; global knowledge networks; joint research venture

JEL Classification: I23 L24 O19 O32 


\section{Introduction}

There are many studies of both the globalization of research and development (R\&D) and the internationalization of higher education. However, less attention has been given to what is happening at the intersection of these trends. In particular, research universities around the world are increasingly expanding their institutional R\&D research presence overseas through the creation of research centers, facilities and partnerships outside of their home countries. Examples of these international university research ventures (IURV) include research centers of such leading universities as the Massachusetts Institute of Technology (MIT), the University of Cambridge, and the Technical University of Munich established at the CREATE campus in Singapore (CREATE 2017); R\&D facilities at the campus of Georgia Institute of Technology in Lorraine, France (Georgia Tech 2017; Schmid et al., 2017); the research programs of Carnegie Mellon University in Qatar (CMU 2017a) and Portugal (CMU 2017b); and the Fudan-Yale Biomedical Research Center in China (Yale University 2017).

The focus of this study is on IURVs as initiatives in the internationalization of university research at the institutional level, as distinct from the micro-level of transnational individual or group scientific collaborations, or macro-level "big science" (de Solla Price 1963) through Intergovernmental Research Organizations and other multination research cooperation frameworks. While there is a burgeoning literature on the internationalization of higher education and of science, to date there has been relatively little specific attention to IURVs. Outside of a few notable case studies, there is a lack of comprehensive analysis of IURVs, their emergence and worldwide proliferation. Nor is there any systematic assessment of their activities and outcomes, uses of knowledge, impacts on global knowledge transfer, and broader economic, societal and security implications.

We identify the need for a better understanding of the worldwide landscape of IURVs and the channels and drivers of their global expansion. Multiple questions immediately arise: How can IURVs be delineated and what is the scope of their activities? What is the scale, time trends, and geographical distribution of worldwide IURV expansion? In what organizational forms, networks and research topics are IURVs engaged? What types of universities tend to establish IURVs? What are the drivers and pathways of IURV emergence? Are they strategic or opportunistic; top-down, led by university administrations, or bottom-up, evolving from faculty collaborations? And, most fundamentally, how can we explain the global emergence and significance of IURVs?

This study explores these questions through a systematic data collection effort on, and analysis of, IURV activities of top research universities in the United States. We propose a conceptual framework that positions our empirical findings about drivers and pathways of IURV emergence in the context of existing theoretical and empirical literature on the expansion of collaborative science, university internationalization, and growing efforts of governments around the world to improve their domestic capacity in science, technology and innovation.

The next section of the paper provides an overview of previous scholarly work related to the IURV theme. In following sections, we put forward a conceptual framework for understanding IURV emergence, describe methodological aspects of our data collection, and present the main empirical findings. We then apply the conceptual framework as means of analyzing and explaining these findings. The final section concludes with a summary of the main results and suggests directions for further research.

\section{Background}

As indicated in the introduction, we define IURVs as formal and organizationally consolidated research operations set up by home country universities through the establishment of research centers, facilities and other institutionalized research partnerships in foreign countries (see also Youtie et al. 2017). Potential explanations, motivations and pathways for IURV emergence can be inferred from the extant literature on other types of trans-border knowledgeproducing organizations with which IURVs may have some commonalities. Probably the most well-studied among these types is the multinational R\&D unit created by a private company outside of the country of origin. Firms often establish such ventures with international partners as a substitute for internal R\&D (Allen and Link 2015). They do so in order to cope with the uncertain nature of technologies and to increase the success rate of R\&D while reducing financial risks through sharing $R \& D$ costs with partners (Vonortas 1997). In recent decades, universities have emerged 
as one of the leading participants in joint research ventures with firms (Link and Scott 2005; Li 2010), while access to universities has become one of the primary motivations behind strategic decisions to locate multinational R\&D units (Thursby and Thursby 2006). Other prominent strategic motivations include access to market and the relative strength of a country's science base (Kuemmerle 1999; Von Zedtwitz and Gassmann 2002). There is also evidence that firms respond to policy incentives to establish joint research ventures with partners in other countries (Allen and Link 2015).

Besides multinational firm $R \& D$, research organizations in the public sector are also engaged in creating trans-border research ventures. Jonkers and Cruz-Castro (2010) studied the emergence of international joint research laboratories and found a total of 160 joint labs established between 1993 and 2008, with nine of them created by U.S. universities. Our findings suggest that the actual number of IURVs established by U.S. universities in this period is much higher. However, Jonkers and Cruz-Castro focused mostly on joint ventures initiated by French and German public research institutions (PRIs) rather than by universities. Ebersberger and Edler (2009) also studied the internationalization of PRIs, finding that it was driven more by economic factors for PRIs involved in applied research and by science quality factors for PRIs specializing in basic research. Berger and Hofer (2011) discussed the internationalization of a particular type of PRI - European research and technology organizations (RTOs). They found evidence of strategically planned behaviour in RTO internationalization not unlike that encountered in multinational corporate R\&D joint ventures. Zacharewicz et al. (2017) found that the specific mission orientation of European RTOs set by national governments could create barriers to RTO internationalization.

In contrast to the extensive studies of private firm R\&D internationalization and, to a lesser extent, PRIs, there are relatively few sources that consider international university research ventures. This is despite the significant role that universities play in global knowledge networks (Jones et al. 2008) and the heightened importance of the research function to the mission of contemporary universities (Scott 2006; Youtie and Shapira 2008). We follow a typology proposed by Katz and Martin (1997) in making a distinction between the micro-level of individual or team scientist collaboration, the meso-level of institutional collaboration, and the macro-level of intergovernmental research cooperation. With the exception of a few notable IURV case studies, most of the relevant literature focuses either on the micro-level of individual scientific collaboration (Katz and Martin 1997) or on meso-level transnational education (Knight 2004; Altbach and Knight 2007). Yet an IURV as an institutional-level initiative in research internationalization is invariably a more complex and multidimensional phenomenon than a relatively simple informal research collaboration of several faculty members. Its scope also extends beyond the understanding of university internationalization through the lens of transnational education. Nevertheless, both strands of literature can provide useful insights into the motivations and pathways of IURV emergence.

It is well-recognized that international scientific collaboration has been continuously expanding and intensifying for several decades (Wagner and Leydesdorff 2005; Wagner et al. 2015). Among the factors explaining this growth are the desire of participating institutions and individuals to increase research productivity (Lee and Bozeman 2005) and to pool their knowledge, resources and skills as a response to increasing costs, complexity and interdisciplinarity of science (Katz and Martin 1997; Wuchty et al. 2007; Gibbons et al. 1994; Morillo et al. 2003) and increasing specialization and division of labor in research (Walsh and Lee 2015). Other motivations for collaboration include gaining access to external funding, opportunities for student and personnel training, increased visibility, reputation and recognition (Melin 2000; Beaver 2001), exposure to different research cultures (Barjak and Robinson 2007) and access to sites of specific research interest (Engels and Ruschenburg 2008).

Of particular interest to our topic is that in large-scale, complex and multi-disciplinary scientific collaborations, management challenges, along with institutional pressure from funders and policymakers, may encourage administrators and participants to formalize arrangements and establish a joint research center or institute (Youtie et al. 2006; Corley et al. 2006; Bammer 2008). The international dimension may add even more pressure to institutionalize research collaboration into an IURV to address issues of knowledge appropriation, national security (Krige 2015), and economic competitiveness (Georghiou 1998; Peters 2006). Formalization of such collaboration in an organizational setting allows for the easier and more efficient control over knowledge circulation between different countries. As Georghiou (1998) observes, as a result of these growing pressures formal arrangements between 
collaborating institutions "are beginning to catch up with the very substantial extent of 'bottom-up' global cooperation" (p. 611).

Some of the existing case studies of IURVs are situated in the context of institutionalized research collaboration. A prominent example is Friedman's (2005, pp. 301-304) account of the early history of the Fudan-Yale Biomedical Research Center, a long-standing and productive joint venture between two prominent universities, one Chinese (Fudan University) and one American (Yale University). He observes that the collaboration is based on a division of labor and cost-sharing: researchers based in the IURV at Fudan University conduct labor-intensive laboratory work, while their Yale counterparts do most of the data analysis. As the then Yale president explained (p. $335)$ to the author, "[m]ost of these institutional collaborations arise not from top-down directives of university administrators, but rather from long-standing personal relationships among scholars and scientists." Other case studies of IURVs based in China (Bonnema et al. 2006; Youtie et al. 2017) observed similar IURV characteristics and behavior. These findings suggest that IURVs built on a bottom-up research collaboration tend to be less missionoriented than international ventures established by PRIs. IURVs may also tend to be less governed by strategic intentions, and be more evolutionary, opportunistic and exploratory in the types and topics of research and other activities they pursue than typical multinational corporate R\&D operations.

Still, there are some cases of strategically planned IURV operations which are connected to top-down policy initiatives by host country governments to build up their domestic capacity in science, technology and innovation (STI) through research and innovation partnerships with scientifically advanced nations (Wagner et al. 2001; Engels and Ruschenburg 2008). For less developed countries, these collaborative partnerships may provide solutions to pressing developmental problems such as those related to the Sustainable Development Goals set by the United Nations (2015). As Skolnikoff (1994) notes, science and technology is not a panacea for generating economic benefits because there are limits to the capacity of developing countries to absorb and utilize the knowledge produced in the collaboration. Nevertheless, recent years have seen an expansion of trans-border STI partnerships promoted as tools for international development and capacity building not only in emerging but also in some developed economies. Opportunities and policy incentives are generated to attract foreign knowledge-producing actors, including universities, to come to these countries and engage in partnerships, including through IURVs. The most prominent examples of such "top-down" policy-based approach to IURVs are in Singapore (Pfotenhauer et al. 2013, 2016, Youtie et al. 2017). Other case studies of policy-driven IURVs in Chile (Guimón et al. 2015; Klerkx and Guimón 2017) and France (Schmid et al. 2017) show that original strategic plans and policies for IURV establishment met with the reality of complex challenges and tensions experienced by a trans-border venture simultaneously embedded in institutional environments of a "parent" university and a host partner. Klerkx and Guimón (2017), following observations about international branch campuses by Shams and Huisman (2016), call the challenges that arise from such arrangements a problem of "dual embeddedness." As a result, original plans eventually give way to a more nuanced mixture of "top-down" and "bottom-up" approaches to IURV planning and operations based on learning and local experience.

IURVs can also be a part of the strategic effort of a university to internationalize. Much of the literature on university internationalization is concerned with transnational education, and international branch campus (IBC) development. In the IBC literature, research is typically discussed as a complementary activity to the main educational operations. The Cross-Border Education Research Team (CBERT) at SUNY Albany identified 230 IBCs in operation as of the end of 2015 (Kinser and Lane 2015, 2016). Case studies of IBCs in Singapore (Olds 2007; Sidhu 2009a, 2009b), China (Feng 2013), and France (Schmid et al. 2017) show that a number of IBCs host research centers and programs, sometimes with mixed results. According to Lane (2011), motivations behind IBC establishment include potential profit and institutional prestige. Wilkins and Huisman (2012) examine the causal roles of globalization, institutional environment, cultural factors, and social motivations, especially where developing countries are involved. They confirm that IBCs are a part of the strategic effort of parent universities to internationalize. They also show that some IBC relationships are under tight control by the parent university, while others allow for more responsiveness to the needs and interests of the host country.

It should be noted, however, that IURVs connected to strategically planned branch campuses are a subset among the full IURV population. Even those few case studies of specific IURVs discussed here (Friedman 2005 pp. 301-304; Bonnema et al. 2006; Pfotenhauer et al. 2013, 2016; Hird and Pfotenhauer 2017; Guimón et al. 2015; Guimón 
2016; Klerkx and Guimón 2017; Youtie et al. 2017) show a variety of organizational forms and structures of IURVs, from joint "virtual" collaboration platforms to physical research facilities to standalone institutions without connections to branch campus operations.

Several studies have attempted to synthesize varied case study observations on IURVs into an explanatory framework. For example, Guimón (2016) applies the analogy of a multinational enterprise to university internationalization across all three primary university missions: education, research, and economic development. He distinguishes between market-seeking, resource-seeking, and efficiency-seeking motivations for each of these missions, and shows how they are related to different types of trans-border operations by universities, including IURVs. Pfotenhauer with colleagues (2016) analyse four complex international STI partnerships of MIT supported by governments in host countries (United Kingdom, Singapore, United Arab Emirates, and Portugal) as mechanismsfor domestic STI capacity building. The authors develop a typology of these partnerships based on systems architecture and lifecycle model. Most of these types suggest strategic intentions behind IURV development, although for Singapore they also note the gradual and evolutionary expansion of the scope of the MIT-Singapore partnership. However, their approach is limited only to university ventures with strong government involvement, omitting other types of IURVs from consideration. Hird and Pfotenhauer (2017) also evaluated the impact of the MIT-Portugal program on research system in Portugal, which is still the only comprehensive study of IURV impacts and outcomes to date. Youtie and colleagues (2017) provide an alternative perspective on IURVs, focusing on the process of their structuring and institutionalization. Based on three cases studies in China and two in Singapore, and adopting the model of institutionalization of research collaborations by Youtie et al. (2006) to an international setting, they develop a typology of IURVs which distinguishes between loosely and tightly structured ventures with or without government involvement.

While these models and classifications provide important insights into various aspects of IURVs, they are based on particular cases rather than large-scale mapping. Nonetheless, these cases also hint that there are organizational and geographical differences in IURV types and characteristics. In this study, we further probe these issues. We explain the rise of international university research ventures by proposing a conceptual framework based on drivers and pathways of IURV emergence and supporting it with larger-scale data collection on IURVs created by top U.S. research universities.

\section{Conceptual Framework}

From our review of the literature and its lacunae, we propose that IURVs represent distinctive types of nodes in global knowledge networks which are different from strategically-planned multinational firm R\&D efforts or mission-driven PRI internationalization initiatives. IURVs may emerge either from what was initially a bottom-up international research collaboration or as a response to top-down policy initiatives as host economies seek to build up their capacity in science, technology and innovation. Alternatively, IURVs may be a part of a strategically planned effort of the parent university to internationalize, but the diversity of their organizational forms and activities extends far beyond the usual notion of "international branch campus." The motivations behind IURV establishment may include researchrelated factors such as opportunities for productive research collaborations, specific research problems, access to exceptional talent or specific research sites; economic factors such as getting access to resources, market and external funding; and other factors such as student training opportunities or increased visibility, reputation and recognition.

Understanding the complex interactions between motivations and trajectories of IURV emergence is one of the key objectives of our study. We conceptualize these interactions along two interrelated dimensions: motivations behind IURV establishment and IURV development pathways. This framework builds on previous work on IURV institutionalization in Singapore and China as a response to government involvement and extent of structuring (Youtie et al. 2017). The framework generalizes these categories to enable the classification of IURVs based in global regions with less explicit involvement of government in direct or indirect university-related policy measures than was the case in these two Asian countries.

The observed motivations and drivers of university engagement in IURV partnerships can be broadly divided into internal and external ones. Internal motivations, such as seeking resources and reputation or supporting academic 
entrepreneurship by individual researchers, are driven from within the university. External motivations are driven primarily from or by host countries, partners and other external actors, including development agencies and international organizations. Examples of external motivations include host country demand for a partnership with the university as a tool of domestic STI capacity building or as a way of solving specific domestic problems that call for unique research capabilities or skills available at the foreign partner university.

The pathways of IURV emergence and development can be classified as planned or responsive. Planned pathways represent the active engagement of partners at the institutional level, for example, through the realization of university internationalization strategies or national STI policies. Responsive pathways suggest a more evolutionary, opportunistic and exploratory approach of universities to IURV establishment and operation, where university administrations and their partners exhibit receptive behavior towards the emerging opportunities and benefits of institutionalized international research collaboration. A typical case in point is allowing a productive and complex research collaboration to evolve naturally into a prominent joint international research center.

The matrix of IURV pathways and motivations is presented in Table 1. Planned and internally motivated IURVs will fall into the upper left cell of the table. A typical example of such an IURV is a research outpost or research program hosted by the international branch campus of the university created in accordance with the university internationalization strategy. We will call such a case a strategy-driven IURV.

Table 1 IURV typology based on motivations and development pathways

\begin{tabular}{|c|c|c|c|}
\hline & & \multicolumn{2}{|c|}{ Development Pathways } \\
\hline & & Planned & Responsive \\
\hline \multirow{2}{*}{ Motivations } & Internal & $\begin{array}{l}\text { Strategy-driven IURV } \\
\text { IURV is part of university strategy }\end{array}$ & $\begin{array}{l}\text { Collaboration-driven IURV } \\
\text { IURV evolves from individual research } \\
\text { collaboration }\end{array}$ \\
\hline & External & $\begin{array}{l}\text { Policy-driven IURV } \\
\text { IURV is part of host country policy or } \\
\text { partner strategy }\end{array}$ & $\begin{array}{l}\text { Problem-driven IURV } \\
\text { IURV is a response to host country or } \\
\text { partner problems and needs }\end{array}$ \\
\hline
\end{tabular}

Source: Authors' conceptualization

Responsive and internally motivated IURVs in the upper right cell of the table will typically evolve from pre-existing trans-border research projects and collaborations of individual researchers working for the university. We call this type a collaboration-driven IURV.

Planned and externally motivated IURVs in the lower left cell of the table are expected to be driven by external demand and develop in a highly organized and planned manner following the external partner's goals and objectives. Different types of external actors can create such demand, from state agencies to commercial firms to nongovernmental organizations. However, the most prominent type of such partner in existing IURV case studies is the host country government interested in creating a research partnership with the university as a tool for STI capacity building. Therefore, we call this type a policy-driven IURV.

Responsive and externally motivated IURVs are presumably created in response to particular problems and needs of the host country but without strategic planning on both sides of the partnership. A typical case in point would be a developmental problem which calls for research and experimentation but without a specific time frame or expected pathways for its solution. This case is a problem-driven IURV.

An important caveat in applying this typology is that the proposed types are not exclusive, because there is a potential multiplicity of actors and, therefore, motivations involved in IURV creation and development. It is entirely plausible, for example, to observe an IURV established as a part of both university and host country strategies. To avoid confusion, we first focus on the motivations of the main institutional partners, since an IURV by our definition is an institutional-level activity. Second, in our empirical analysis, we anticipate finding varying IURV types that will underscore essential differences between them. In subsequent sections, we present our data approach and results from applying the conceptual framework and typology presented here to the analysis of the data. 


\section{Data and Methods}

\subsection{Overview}

For this study, we have undertaken the first systematic effort to collect data on IURVs created by top U.S. research universities. Information on relevant university characteristics, internationalization strategies, IURV locations, years of operation, partnerships, research areas, missions, activities, and organizational forms was manually collected from websites of participating universities, their partners, and IURVs themselves. Additional information was gained from relevant government reports, scholarly publications and news sources. A two-layer comprehensive database was constructed to store the collected information about research universities (the university layer) and their IURVs (the IURV layer). IURV location data collected in this process was mapped and analyzed using the ArcGIS software package to construct worldwide, regional and country-level aggregate geographical distributions of IURVs and their principal characteristics. Differences between these characteristics for different regions and countries were analyzed to identify potential clusters of similar IURVs that could help test the conceptual framework behind the proposed IURV typology.

\subsection{Operationalization of Definition}

In the introduction, we defined an IURV as a formal institutional initiative undertaken by a university to establish a long-term research presence overseas through the creation of a research center, facility or partnership outside of the home country. Applying this generalized concept to inherently variable website data on complex real-world initiatives, organizations and partnerships required substantial judgment in data collection and coding processes. To increase the cross-coder validity of data and productively operationalize the concept, the list of specific criteria for IURV identification was gradually refined through a process of collective iterative deliberation based on data collection experiences and theoretical considerations. The criteria were finalized after the first round of data collection and used in the subsequent rounds of data validation and cleaning. IURV identification was based on the following criteria:

1) The IURV should be an institutional-level initiative advanced by the university or its constituent units (colleges, departments, schools, etc.), as distinguished from an individual-level, team-level or an intergovernmental effort described in Katz and Martin's (1997) typology, or from multilateral international collaboration frameworks and organizations typical for "big science" (de Solla Price 1963).

2) The IURV should demonstrate explicit evidence of research activities directly performed at or clearly associated with it and conducted outside of the country of origin.

3) The IURV should possess the formal characteristics of an organization, such as name; purpose (identified by goals, missions, declared research focus, etc.); membership; and governance structure.

4) The IURV should have a parent organization, and by our definition, it should be a university. This role is determined either by the declared institutional affiliation (often explicitly in the name of the venture), or, if several partners are involved, by the designation of a particular university as the principal partner or coordinator of the venture. We found two cases where two or three U.S. universities jointly entered the IURV partnership in another country on seemingly equal terms. In these cases, all participating universities were equally counted as parent universities.

5) The IURV should have a "host" in another country. Note that a host can be either an independent organization, such as a foreign university, a government agency, or a research institution; or a distinct physical location, such as an international branch campus or foreign science and technology park.

Based on these criteria, we restricted the scope of data collection by excluding the following initiatives and entities from consideration: individual research projects with an international dimension; international branch campuses and study abroad programs focused only on teaching; international liaison offices engaged only in student recruitments, alumni relations, or travel services; international development initiatives with a physical presence in other countries but without a research component; standalone student and faculty exchange programs; and formal agreements, such as memoranda of understanding between institutions. 
We note that formal institutional agreements are, of course, necessary to establish an IURV. However, they are not sufficient to create an operating joint venture even if establishing it is the explicit objective of the agreement. In many cases, formal agreements target activities unrelated to research, or remain dormant without any actual activity at all. We also excluded large-scale inter-governmental initiatives in research cooperation and large networks of multiple actors interacting in a transnational setting, such as university alliances, or multi-country, multi-partner developmental partnerships that did not have a clear leader or host. An example of an excluded case is the U.S.-China Clean Energy Research Center (CERC) established by the U.S. Department of Energy and three Chinese ministries. This research consortium includes universities on both sides in various roles. However, they are participants in a largescale and complex cooperation scheme established between two national governments. Thus, CERC is excluded from consideration based on our definition.

Despite their complexity, these criteria allowed us to lower the number of borderline IURV identification cases that caused sorting difficulties to about ten university initiatives falling either within or outside the final IURV list.

Our operationalization strategy also required understanding and disentangling complex relationships and interactions in IURV partnerships, so as to classify partners into distinct roles of parents and hosts. In most cases, it was relatively easy to do this because of the declared affiliations, partnership structures, and attached physical facilities. However, in a significant number of cases, joint research ventures were found to be built on a symmetric partnership. In these cases, there are either twin physical centers based at each partner's location or the collaboration is established as a joint "virtual laboratory". In such cases, we consider both partners simultaneously as parents and hosts. Since our focus at this stage is on U.S. universities as parents rather than hosts, this classification issue did not create any significant difficulties in analysis of our results.

\subsection{Sampling, Data Collection and Limitations}

Our sample is restricted to top U.S. research universities identified in the Carnegie Classification of Institutions of Higher Education, 2010 edition, as being a "Doctoral/Research University - Very High Research Activity" (Carnegie Foundation for the Advancement of Teaching, 2011). The 2010 edition contains 108 such universities. To characterize the scale, scope and features of IURVs established by universities in the sample, our research involved the extensive and rigorous construction of a database that included information on both the parent university in the home country and its international research locations (IURVs in host countries).

We gathered and reviewed IURV-related information obtained primarily through a manual collection of information from the websites of universities and their IURVs, supplemented by data gathered from partners' websites, academic publications, government reports, and relevant news sources whenever available. We collected two types of data: information about the parent university, including its basic characteristics and data on its international division and international strategy; and information about its IURVs in host locations. Universities often distinguish between "internationalization at home", which includes activities targeting international students and foreign scholars at the home campus and research with an international focus (e.g. area studies or international relations), and "internationalization abroad" which covers all university activities conducted outside the home country, including international research collaborations and IURVs. Since our focus is on internationalization abroad, we excluded from consideration international divisions that focused only on internal internationalization activities, such as typical international student and scholar services (ISSS). For each international division that coordinates internationalization abroad, information was gathered on its location within the administrative hierarchy of the university, number of staff associated with the office, its missions and goals, existence and contents of a dedicated strategic plan for internationalization, and IURV numbers and locations outside the U.S., whenever available. Websites specifically created for or indirectly related to identified IURVs were reviewed to gather information about their location, organizational form, missions, years of operation, disciplinary fields, partnership structures, the scope of activities, physical assets, and staffing.

Regarding topical focus, the effort concentrated on IURVs working in science, technology, engineering, mathematics, medical and agricultural research, and social sciences, while arts and humanities were excluded. Data 
collection was conducted in three rounds and supported by cross-coder validation to ensure reliability. The process concluded in June 2016. A limitation of our approach to data collection is that universities vary in how they present their international activities on their websites. It is conceivable that not all IURVs are listed in university public web pages. However, since U.S. research universities tend to be open institutions and because IURVs are generally viewed as prestigious partnerships that are worthy of visibility, it is unlikely that the number of unreported IURVs is large. To ensure completeness, our search went beyond top-level university pages to include college, school, and departmental level websites. We also examined websites from research-intensive host country institutions to see if we were missing any research ventures.

We acknowledge that our data is biased toward surviving IURVs: universities tend to delete information about concluded or, especially, failed ventures from their web pages. IURVs that were founded and closed before the advent of the World Wide Web in the early 1990s are likely not captured by our search approach. We thus might have missed a number of earlier IURVs. However, to account for potentially missing cases, we used secondary sources of information, including partner websites, news sources, academic publications, policy reports, and the Wayback Machine (https://archive.org/web) which archives deleted, updated and replaced web pages. While this approach cannot fully solve the problem of survivorship bias, we were still able to identify a significant number of IURVs that ceased operations or became independent.

\section{Empirical Findings}

\subsection{Parent Universities}

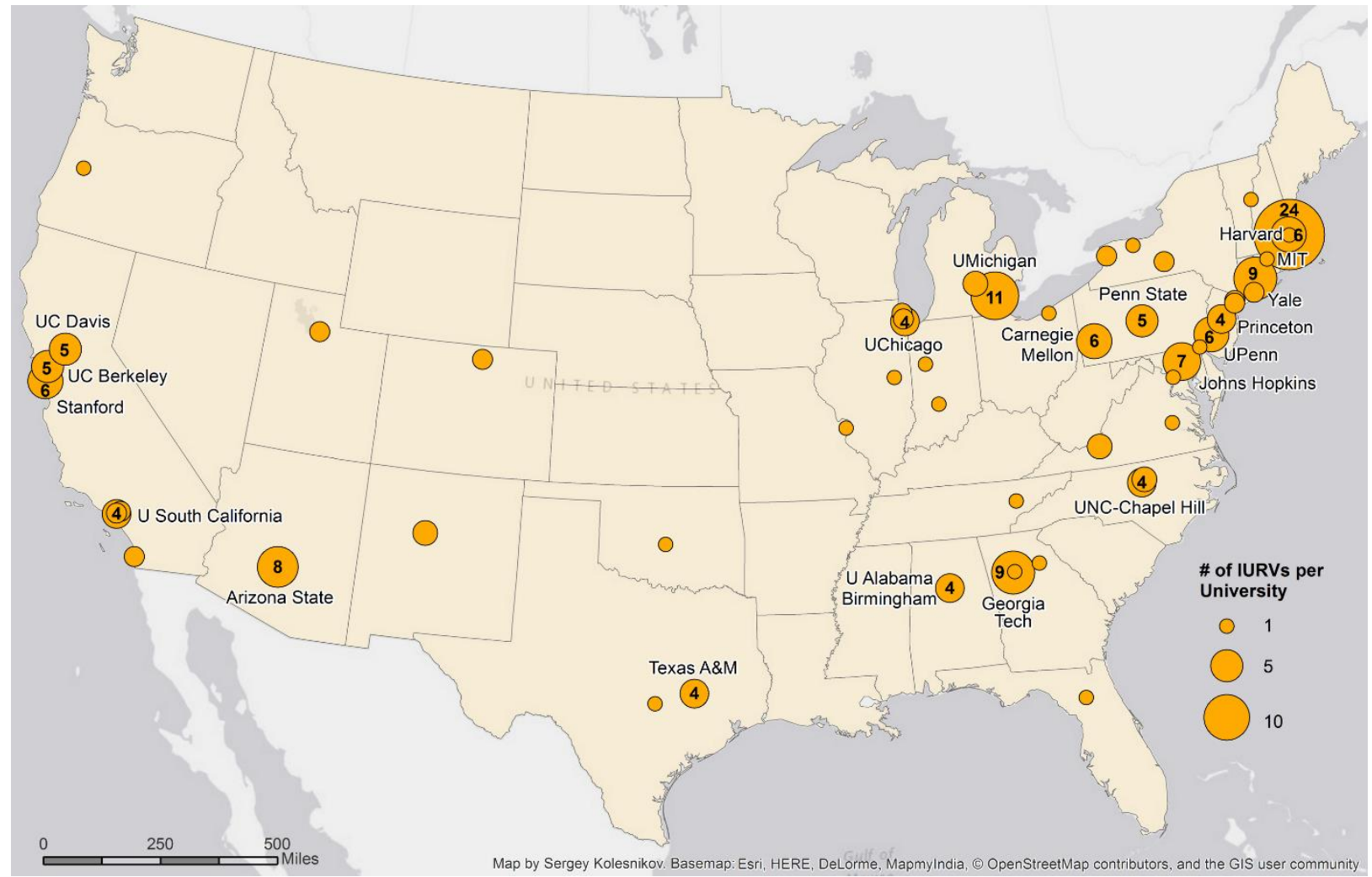

Fig. 1 Locations of 54 top U.S. research universities engaged in IURVs. Source: see Appendix. IURV numbers and university names are shown only for universities that established at least 4 IURVs

Based primarily on disclosures on university websites, we found that half of top American research universities in the sample (54 out of a total of 108 universities) have established at least one IURV. As expected, the number of IURVs operated by universities varies considerably. Nineteen of these 54 universities created only one IURV; another 16 are 
engaged in two or three IURVs, with a further nine in four or five IURVs. The list of top IURV "exporters" with six or more IURVs contains 10 universities, including MIT with 24 IURVs, the University of Michigan with 11, Georgia Institute of Technology (9), Yale (9), Arizona State University (8), Johns Hopkins (7), Carnegie Mellon (6), Harvard (6), Stanford (6), and the University of Pennsylvania (6). A list of IURVs identified for top U.S. research universities in the sample is available in the Appendix. The total number of unique identified IURVs, including those which are no longer in operation, is 183 .

IURV-sending universities are mostly clustered around the East Coast and California, with some presence in the Midwest (Fig. 1). Universities with IURVs also tend to be older and higher ranked elite institutions than their counterparts without IURVs. Private universities are more likely to establish IURVs than are public universities, with $63 \%$ of the former having IURVs compared to about $43 \%$ of the latter. Potential explanations for these findings include financial or state governance limitations that may affect public university propensity for international engagement; greater availability and flexibility of resources for internationalization in private and top-ranked universities, including larger endowments and research budgets; or greater reputational demand for top-ranked universities among host countries.

International activities related to research or external partnerships are relatively high on the administrative agenda of the sampled U.S. universities: most of them ( 86 out of 108) have established international divisions that coordinate their "internationalization abroad" efforts, with an overwhelming majority ( 82 out of 86 ) reporting to the office of the provost, vice president, or another highly ranked administrator.

Having a dedicated internationalization strategy for activities beyond just international education is less common. Only 47 universities were found to have any such plan, either as a separate document or as a dedicated chapter in a university-wide strategy. Moreover, these strategic documents rarely mentioned goals or objectives connected to IURV-related activities. Also, there is little correlation between the presence of IURVs and the availability of a non-educational international strategy in the university. These surprising findings suggest that at least for the U.S. research universities, IURVs are not a high strategic administrative priority. It also suggests that IURVs are more likely to emerge opportunistically in a gradual evolution of international research collaborations or under external demand rather than as a result of the strategically planned action by university administrators.

\subsection{IURVs}

We found a total of 183 unique IURVs created by 54 top U.S. research universities located in 59 countries. By the summer of 2016, 163 IURVs were in operation or planning stages, while 20 had ceased operations or had become independent entities.

\subsubsection{Geographical Distribution}

The worldwide geographical distribution of U.S. IURVs is presented on the map in Fig. 2, while absolute numbers for countries hosting two or more IURV are shown in Fig. 3.

China hosts the largest number of U.S. IURVs with 42. Singapore follows with 10 IURVs, then Qatar and South Korea with eight each. The rest of the distribution is dispersed: U.S. IURVs are hosted by some of the most and the least developed and scientifically advanced nations, suggesting significant heterogeneity in motivations behind IURV creation.

Developed countries and territories that host IURVs include Singapore, South Korea, Ireland (5 IURVs), Portugal (4), Japan (4), Spain (3), the United Kingdom (3), Germany (2), France (2), Israel (2), Taiwan (2), and Hong Kong (2). Many of these not only possess relatively high scientific capacity that attracts international research collaborations but also provide (or provided in the past) support for partnerships with U.S. universities through dedicated policies and funding. This latter characteristic is a possible explanation for the higher number of IURVs in these countries relative to Italy (1), Sweden (1), or other European countries that do not host any identified U.S. IURVs. We did not identify any U.S. IURVs in Canada. Geographical proximity and similar academic cultures make collaboration between universities in these two countries relatively straightforward, possibly lessening any demand for institutionalized IURVs. 


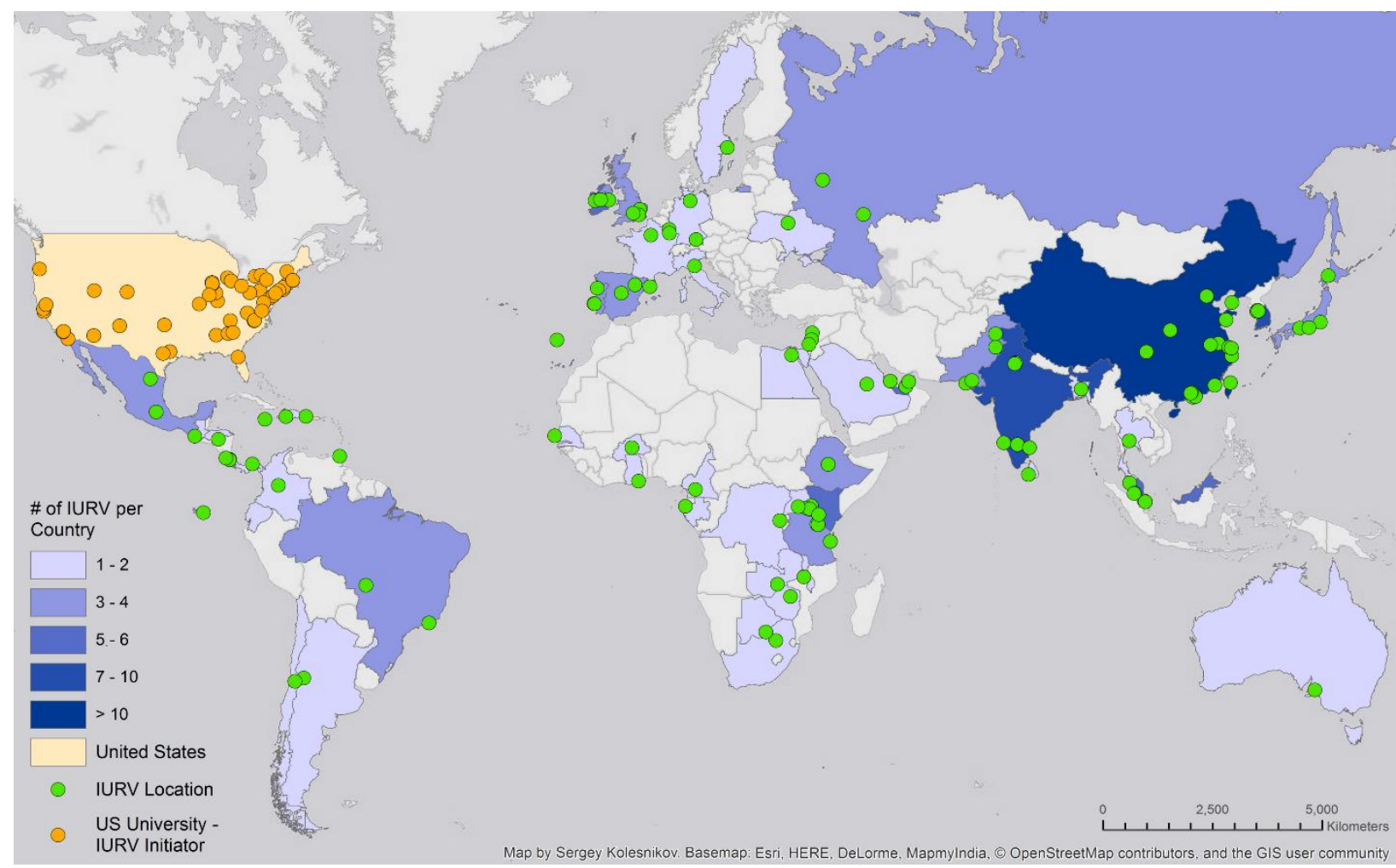

Fig. 2 Locations of international university research ventures established by top U.S. research universities. A total number of identified unique IURVs is 183. Source: elaboration of authors' data. IURV counts in each location are not shown

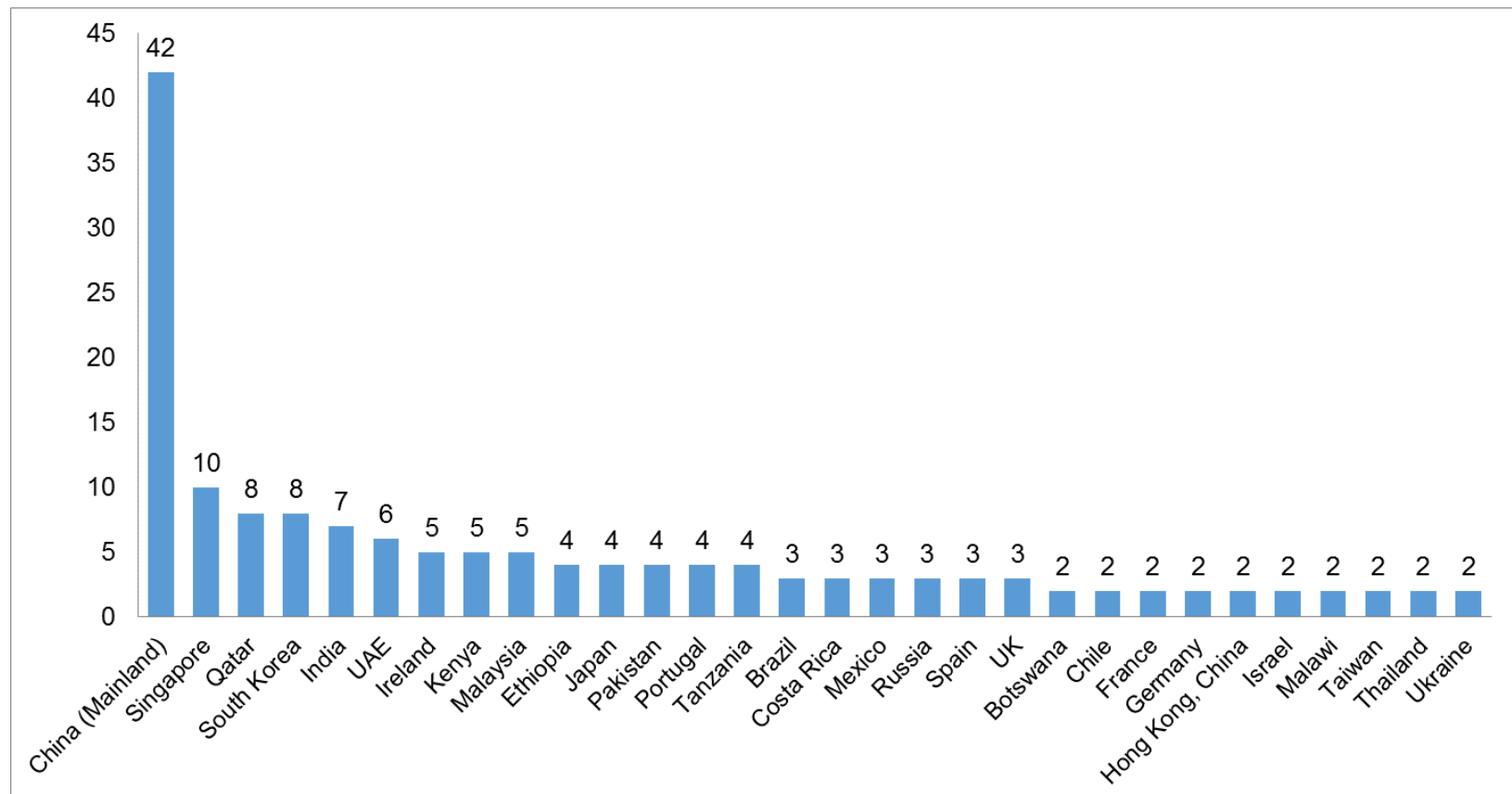

Fig. 3 IURV counts for countries hosting two or more ventures with top U.S. research universities. Source: elaboration of authors' data. Hong Kong, with its distinctive governance system and history of university development, is considered separately from mainland China. 
Among countries that are less developed or scientifically active, Kenya hosts five U.S. IURVs, Tanzania, Ethiopia, and Pakistan have four each, and Malawi and Botswana each host two. IURVs in these countries are mostly working in the international development context, often oriented towards applied solutions to public health problems or basic developmental needs. With the exception of Ethiopia, these countries are also former British colonies where English remains an official language. This observation shows the role that common culture, language and history may play in joint research venture location decisions (Zitt et al. 2000).

In the middle ground are emerging economies which may currently lack domestic scientific capacity, but nevertheless recognize the importance of $R \& D$ investment and have allocated resources to support it. Many of them have policies in support of international research collaborations and domestic STI capacity building, and some proclaim knowledge-based economy development as a cornerstone of the national strategies. Among these countries are Qatar, India (7 IURVs), United Arab Emirates (5), Malaysia (5), Russia (3), Brazil (3), Mexico (3), Costa Rica (3), Chile (2), Thailand (2), and Ukraine (2).

China is a clear standout among these groups. Over the past two decades, China has made massive investments in $\mathrm{R} \& \mathrm{D}$, fostered the development of universities, and promoted international research collaborations (including joint research ventures). China has become a major "scientific power," and is now second in the world, after the United States, in terms of gross publication output (National Science Board, 2016). It is not yet clear how IURVs based in China have contributed to this growth (Jonkers 2009), although they may have helped in providing models, training, and reputational spillovers and also assisted home university partners in accessing the burgeouning Chinese research system. In any case, the high number of U.S. IURVs hosted by China potentially reflects its rising scientific power as an attractor for international research collaborations, as well as a response to Chinese STI policies and available support, especially from provincial and city governments.

Overall, more than three-quarters of IURVs (141 out of 183) are (or were) hosted in 44 countries that are not part of the Organisation for Economic Development and Cooperation (OECD). Regarding regional distribution, Asia clearly leads with 106 IURVs, followed by Africa (28), Europe (27), and Latin America (21). Oceania hosts only a single U.S. IURV, which is notable given the strength of Australian universities' internationalization efforts. Other regions that lack U.S. IURVs include Eastern Europe, Central Asia, and North Africa.

\subsubsection{Time Trends}

Our findings, despite potentially suffering from a survivorship bias (see Section 4.3), indicate that the expansion of IURVs is a relatively recent phenomenon. While the earliest U.S. IURV in the sample (Johns Hopkins's SAIS Europe joint center with the University of Bologna in Italy) has been in operation since 1955, a significant growth in IURV entry started only around the turn of the current century and has continued to this day. The majority (167) of IURVs were created after 2000, and a peak of 18 new entries was reached in 2013 (see Fig. 4). Meanwhile, IURV exits have remained modest: only 20 IURVs in our database ceased operations or became independent.

The IURV annual entry trend data suggests three cohorts. Cohort A refers to U.S. IURVs established during 1955-1999. In addition to the aforementioned SAIS Europe, this cohort also includes some of the early cases of MIT participation in developmental and STI capacity-building initiatives that had a research component, and Georgia Tech's campus in Lorraine, France, founded in 1990, with its early efforts to establish an overseas research program (Schmid et al. 2017). Cohort B refers to IURVs created during 2000 to 2007. This period, which is often regarded generally as an intense era for globalization, marks the start of the rapid expansion of IURVs and national policies that encouraged the development of universities, most notably in China (Zhang et al. 2013). Cohort $C$ refers to the post-recession era (2008-2016). During this period IURV entry accelerated further, in part as a response to a new wave of STI capacity building policies such as in Singapore (Sidhu et al. 2014) and in part as a result of shrinking budgets of public universities and a (temporary) decline in private R\&D during the recession, which may have contributed to universities' seeking external resources for research outside their home base. However, after 2013 we see a deceleration of IURV entries, suggesting either an exhaustion of resources for IURV creation offered by host countries or saturation of organizational and managerial capacity or interest of top U.S. research universities to engage in IURV activities abroad. Whether this decline will persist in the future remains an open question for now. 


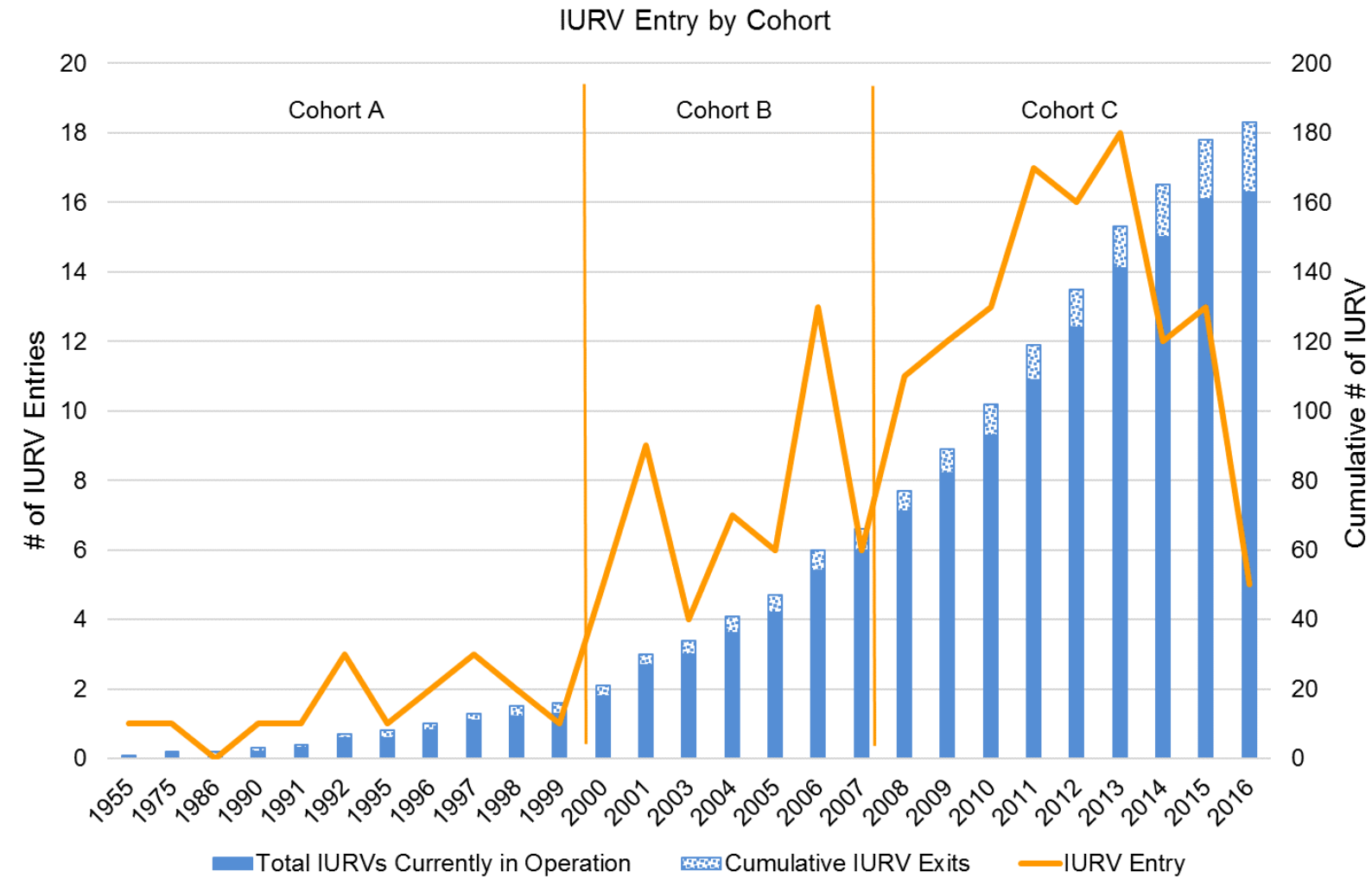

Fig. 4 Time trends in annual U.S. IURV entry (line), accumulation (solid bars) and exits (dotted bars), 1955 2016. Source: elaboration of authors' data. Left-hand scale indicates annual IURV entry; right-hand scale indicates the accumulation of IURV entries and exits

\subsubsection{Research Areas}

We gathered information about the topics of research conducted at IURVs and manually classified them into research areas according to the most recent OECD (1997) classification of Fields of Science and Technology (FOS). IURVs can engage in multiple and different research topics. In our data collection strategy (see Section 4.3), we focused on IURVs with research corresponding to these five categories (with FOS initial digit): Natural Sciences (1), Engineering and Technology (2), Medical and Health Sciences (3), Agricultural Sciences (4), and Social Sciences (5). Humanities (6) were out of our scope, although in a minority of cases IURVs engaged in the first five fields also reported humanities research.

In total, 35 out of a total of 37 two-digit research fields in five surveyed OECD FOS one-digit categories were represented in the data, suggesting a very broad coverage of scientific fields for research conducted by IURVs (Table 2). The most common areas are health sciences (50 IURVs) and environmental engineering (38). Various branches of social sciences are also well-represented. Many IURVs are involved in multiple research fields. Hence the numbers of fields in Table 2 sum to more than the total number of IURVs.

The geographical concentration of IURV research specializations is presented in Table 3. The research profiles of IURVs are similar in Europe and Asia, with the relatively higher prominence of social sciences in Europe. In Latin America, the intensity of IURV research in natural sciences is on the same scale as in Europe and Asia, while engineering and technology, and medical and health sciences are less represented. The most common area of research there is in social sciences, involving $67 \%$ of all IURVs in the region. A possible explanation for this finding is in efforts of American universities to open up research offices in Latin America that perform contract research and consulting in areas related to economics, business, logistics, and management. 
Table 2 Leading IURV Research Fields

\begin{tabular}{lr}
\hline Two-digit OECD Research Fields & Number of U.S. IURVs \\
\hline 3.3 Health sciences & 50 \\
2.7 Environmental engineering & 38 \\
3.2 Clinical medicine & 36 \\
2.2 Electrical engineering, Electronic engineering, Information engineering & 30 \\
1.2 Computer and information sciences & 29 \\
5.2 Economics and Business & 27 \\
5.7 Social and economic geography & 26 \\
1.6 Biological sciences & 25 \\
1.5 Earth and related Environmental sciences & 23 \\
3.4 Medical biotechnology & 21 \\
2.6 Medical engineering & 20 \\
2.11 Other engineering and technologies & 20 \\
\hline
\end{tabular}

Source: Elaboration of authors' data. Note: Table presents research areas pursued by 20 or more IURVs. Number of research fields exceeds IURV count (183) because many IURVs work in more than one research area.

Table 3 U.S. IURV research specialization by region

\begin{tabular}{|c|c|c|c|c|c|c|}
\hline \multirow[b]{2}{*}{ Region } & \multirow[b]{2}{*}{$\begin{array}{l}\text { Total number } \\
\text { of U.S. IURVs } \\
\text { in the region }\end{array}$} & \multicolumn{5}{|c|}{$\%$ of regional IURVs working in one-digit OECD research areas } \\
\hline & & $\begin{array}{l}1 \text { Natural } \\
\text { Sciences }\end{array}$ & $\begin{array}{l}2 \text { Engineering } \\
\text { and Technology }\end{array}$ & $\begin{array}{c}3 \text { Medical } \\
\text { and Health } \\
\text { Sciences }\end{array}$ & $\begin{array}{l}4 \text { Agricultural } \\
\text { Sciences }\end{array}$ & $\begin{array}{l}5 \text { Social } \\
\text { Sciences }\end{array}$ \\
\hline Asia & 106 & $37 \%$ & $48 \%$ & $46 \%$ & $7 \%$ & $29 \%$ \\
\hline Africa & 28 & $18 \%$ & $25 \%$ & $64 \%$ & $18 \%$ & $14 \%$ \\
\hline Europe & 27 & $41 \%$ & $48 \%$ & $48 \%$ & $11 \%$ & $52 \%$ \\
\hline Latin America & 21 & $48 \%$ & $33 \%$ & $33 \%$ & $10 \%$ & $67 \%$ \\
\hline Oceania & 1 & $100 \%$ & - & - & - & - \\
\hline World & 183 & $36 \%$ & $43 \%$ & $48 \%$ & $9 \%$ & $34 \%$ \\
\hline
\end{tabular}

Source: Elaboration of authors' data. Note: research fields aggregated to single-digit OECD FOS categories are presented. Specialization is measured as a ratio of the number of IURVs focused on a particular research field in the region to the total number of IURV in the region. Percentages do not add up to $100 \%$ because many IURVs work in more than one research area

In contrast with other regions, the IURV research profile in Africa is different. All research fields except medical and health sciences are relatively underrepresented, while the specialization of African IURVs in the latter is higher than in any other region. IURVs in this region are predominantly engaged in research related to infectious diseases, including HIV, and to basic healthcare provision - both topics directly related to the United Nation's Sustainable Development Goals and funded by various international organizations and philanthropic foundations.

\subsubsection{Organizational Forms}

The organizational forms of IURVs are very diverse. They include formal joint research centers, physical overseas research offices and facilities, and research programs hosted by international branch campuses. Research activities were also found in: overseas extension offices and technology transfer centers seeking to adapt technologies developed by the parent university to local conditions; international outposts and liaison offices providing researchers with funding and facilities to conduct research at their locations; capacity- and institution-building developmental 
partnerships involving a research component; dyadic comprehensive university research alliances; and complex science, technology and innovation partnerships, to use the terminology of Pfotenhauer et al. (2016).

Eighty-six IURVs in our sample explicitly state that they have dedicated physical facilities, laboratories, and research equipment. At the same time, about one quarter of the total, or 55 IURVs, operate mainly in the form of joint virtual research institutes/centers - collaborative research platforms with the characteristics of a formal organization, but without a designated physical location or, alternatively, two physical sister units situated at both partners' locations. These alliances usually imply a symmetrical partnership between participating parties, a certain degree of division of labor, and sharing of each other's research facilities and equipment. Such virtual labs are most common with China.

Only a small set (21) of the IURVs is actually linked to international branch campuses, confirming our previous observation that the proliferation of IBCs and the expansion of IURVs are different phenomena, although both are related to a broader trend of university internationalization (see Section 2).

\subsubsection{Partnerships}

Our analysis of IURV partnerships shows that IURVs are well-networked. Only four out of the 183 IURVs did not report having any partner. A majority of IURVs - 146 out of 183 - reported having an academic or local healthcare partner, suggesting a strong research collaboration motivation behind their engagement. Seventy-six IURVs are created in partnership with national governments and a further 23 with regional or local governments. A majority of these IURVs are involved in various STI capacity-building, institution-building, or regional economic development partnerships. Forty-one IURVs work in collaboration with or are funded by international development organizations, such as the United Nations Food and Agriculture Organization, World Bank, the U.S. Agency for International Development (USAID), philanthropic foundations, and local community-based non-governmental organizations (NGOs). These IURVs are mostly concentrated in areas of operation of international development programs, including Latin America, South Asia, and Africa. Finally, 36 IURVs reported collaboration with industrial partners, suggesting a revenue or market-based motivation for university engagement in these IURVs as well as a potential focus on commercialization of research produced in the framework of IURV collaboration.

\subsubsection{Scope of Activities}

As we hypothesized earlier based on the existing literature and case studies, IURVs tend to engage in activities beyond or complementary to research and pursue a variety of additional knowledge-exchange and developmental objectives. To test this, we classify the multiplicity of IURV activities and partnerships into four broadly defined mission categories: research, education, commercialization, and development. All entities in our dataset by definition have a research mission. One hundred twenty-seven IURVs are classified as having an education mission if they have reported offering educational courses, training programs, certificates, or full-scale degree programs. The commercialization mission is attributed to 71 IURVs that claim participation in commercialization or technology transfer activities, have an associated business incubator (we found ten such IURVs), or have a private corporation as a partner. Finally, the development mission is assigned to 87 IURVs which explicitly claim their role in host country economic development efforts, including STI capacity building initiatives, or have partnerships with governments, international development organizations, philanthropic foundations, or local community-based NGOs.

Only 15 IURVs are exclusively focused on research alone. All others pursue additional missions. Fifty-six IURVs, or $31 \%$ of the total, are engaged in all four missions. The longer the IURV has existed, the broader the scope of activities in which it is engaged. These observations suggest that in their evolution, operation, and expansion of the scope and variety of activities, IURVs mirror historical and current transformations experienced in universities in general (Etzkowitz 2003; Scott 2006; Laredo 2007; Youtie and Shapira 2008).

\section{Analysis}

Our analysis of the identified IURVs finds that U.S. research university IURV expansion is a global and relatively recent phenomenon. IURVs have been created in some of the most and the least economically and scientifically developed countries of the world. We found a significant heterogeneity of IURV characteristics across different 
countries and regions that suggests different mechanisms, motivations and pathways behind IURV creation and development in particular places.

To identify whether certain IURV types are specific to particular countries and regions and to characterize these types based on the typology developed as part of the conceptual framework presented in section 3, we plot and analyze country-level IURV populations against the country's levels of development and scientific advancement. In this case, level of development is a proxy for the amount of resources potentially available to a U.S. university through an IURV establishment, which may influence the university's strategic behavior in internationalization efforts. As a measure of the level of development, we use the 2015 edition of the Human Development Index (HDI) created by the United Nations Development Programme (2015). One of the most important resources for universities is human capital. HDI includes specific measures for it, leading us to prefer it over traditional GDP-based measures of the level of development.

As a proxy for a nation's level of scientific advancement, we use the total number of publications attributed to the country or territory in Essential Science Indicators (ESI) as of July 2016. ESI (https://esi.incites.thomsonreuters.com/) is part of the InCites science and technology indicator platform, now operated by Clarivate Analytics. ESI indicators are based upon ten-year counts of publications in the Web of Science (WoS). Note that the ten-year window is less than the observed time period of IURV existence (1955-2016) or rapid expansion (2000-2016).

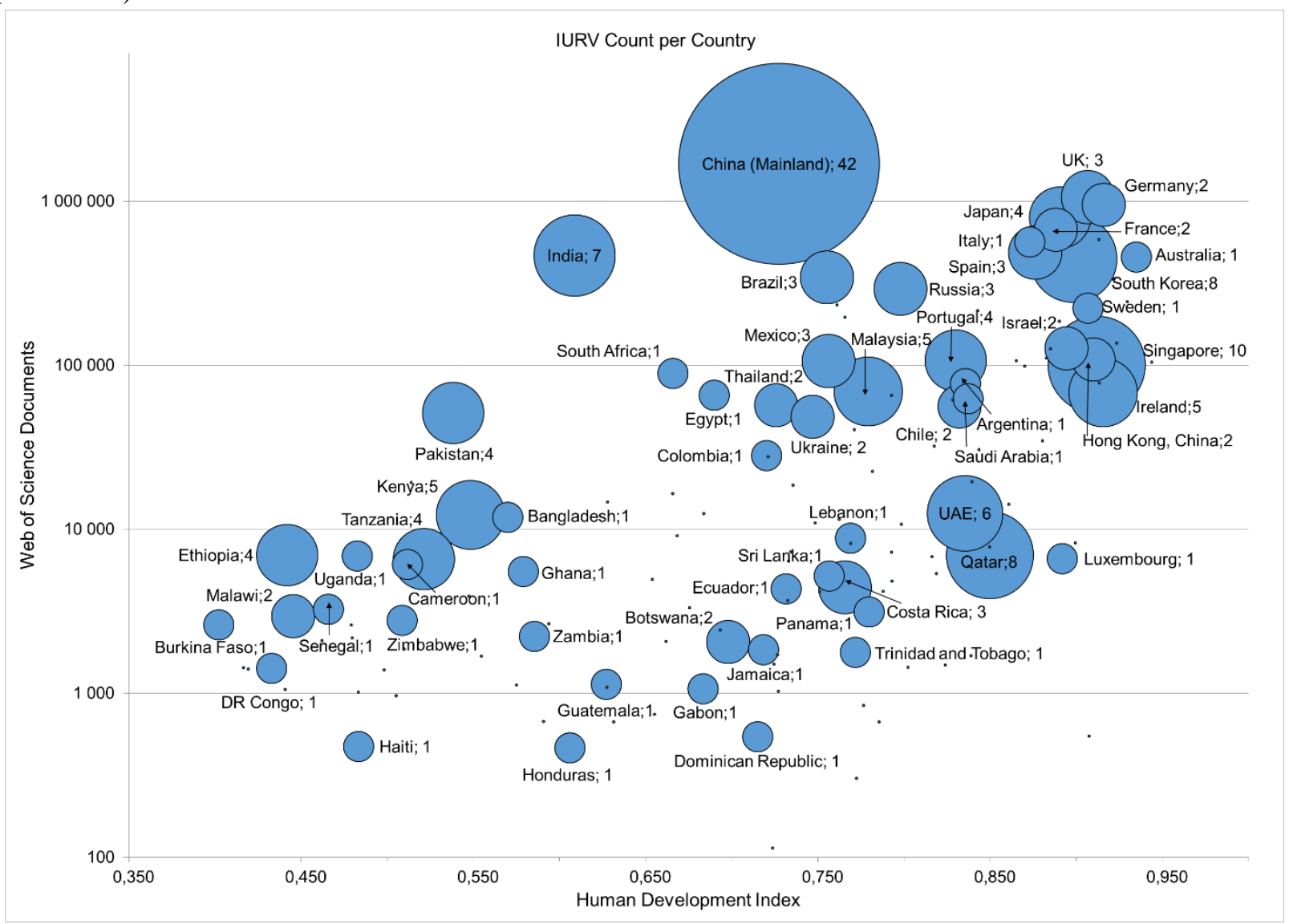

Fig. 5 Country-level IURV populations by levels of scientific advancement and human development. Sources: Essential Science Indicators; United Nations Development Programme (2015); authors' data. Small dots are countries without U.S. IURV presence. Bubbles represent countries hosting U.S. IURVs with the size proportional to the number of IURVs. Total IURV counts are shown, without accounting for IURV exits. Hong Kong is considered separately from mainland China. Taiwan, which has hosted two U.S. IURVs, is not included due to its absence in the 2015 edition of HDI.

We plot publication counts on log scale to account for the skewness of the distribution. Since ESI and HDI are composed for different country sets, we identified 138 countries and territories included in both indices and 
positioned them in the WoS publications - HDI coordinate space. Nations that do not host U.S. IURVs are plotted as simple dots. Fifty-eight IURV-hosting countries and territories that are referenced in both indices are plotted as bubbles with the size proportional to the number of IURVs hosted by them. Country names and the number of IURVs are indicated in each bubble. The resulting plot is shown in Fig. 5.

On this plot, we can identify several distinct clusters of U.S. IURV-hosting countries. First, at the top right corner, there is a small and dense cluster of highly developed and scientifically advanced nations located mostly in Europe and East Asia. Research produced in collaboration with institutions in these countries may result in higher quality publications and higher impact, which might, in turn, lead U.S. university researchers and administrations to pursue such collaborations and establish collaboration-driven or strategy-driven IURVs. Note, though, that we have previously found that there is little connection between university internationalization strategy and actual IURV population, so it is reasonable to expect that strategy-driven IURVs will be in the minority there. This is indeed the case: only several university alliances and branch campus-based research programs fall under the "strategy-driven" category. Another observation is that the highest IURV populations in this cluster are observed for countries where excellent research opportunities are coupled with additional funding and policy support for promoting research collaborations between domestic actors and U.S. universities, such as in Singapore, South Korea or Ireland. This means some of these collaboration-driven IURVs are policy-driven ventures as well.

Next, there is a cluster of IURV-hosting countries that extends horizontally from the bottom left corner of the plot to approximately the middle of the axis. These countries are mostly located in Africa, South Asia, and Latin America. They have relatively low levels of scientific advancement and low to medium levels of development, so they might not be expected to present attractive resource opportunities or policy incentives to external researchers. The paradox is that some of these countries still host many IURVs. These ventures are thus primarily problem-driven IURVs. As our data reveals, the activities of most IURVs in these countries are related to the attainment of United Nations (2015) Sustainable Development Goals, aiming to solve basic developmental problems through research on topics such as infectious diseases or efficient basic healthcare. Lack of resources and funding in host countries for this work is compensated by various international development programs and philanthropic foundations. The reasons behind the choice to locate U.S. IURVs in particular developing countries over similar ones suffering from the same problems are not yet clear and probably involve international development politics, which we will not dig into here. But our data hints that common language and history of previous relationships between countries may at least play a role.

The third cluster contains "catching up" countries that already possess a substantial capacity in science and technology and resources that allow them to create policy initiatives to further improve this capacity through partnerships with U.S. universities. This cluster includes some of the biggest IURV hosts and extends from BRICS countries at the top-center of the plot to the bottom right corner. Some countries in this cluster may lack the scientific power to attract U.S. universities purely by the quality of their research, but resources provided by them through STI capacity building initiatives generously compensate for this disadvantage, making these IURVs a clear case of policydriven ventures. The biggest challenge for these countries is the effectiveness and efficiency of IURVs as a mechanism for the attainment of their national STI policy goals. However, at least for China, researchers and IURVs have become attracted to China by opportunities for excellent research collaboration, in addition to by policy incentives. Thus, China hosts a mixture of collaboration-driven and policy-driven IURVs.

\section{Concluding Remarks}

This paper has presented the results of a large-scale study of international university research ventures created by U.S. universities. We found that IURVs are a growing phenomenon in university internationalization rooted in the continuing trend of expansion and institutionalization of international research collaborations and rising policy demand from host countries for capacity building in science, technology and innovation. However, the evolutionary character of emergence and growth of many of the IURVs makes them distinct from strategic or revenue-driven multinational industrial joint research ventures and, to a certain degree, from the mission-driven internationalization of public research institutions. The focus on research and development, expanding scope of activities, a variety of 
organizational forms, and distinct network-based partnership structures also distinguish IURVs as a prominent form of university internationalization abroad which has characteristics and forms that are not captured by the extant literature focused on international branch campuses. We conclude that IURVs are a distinctive and growing type of intermediary node in international knowledge networks that requires close scholarly attention to evaluate its impact on global knowledge production and transfer, human capital, innovation, economic competitiveness, and international development. A key takeaway from the study is that evaluation studies should not perceive IURVs as a uniform phenomenon. Instead, they should differentiate the impact of different IURV types based on host country policy and development contexts.

Through a framework based on motivations and pathways of IURV establishment, we identified four types of IURVs and analyzed the worldwide geographical distribution of these types. These findings suggest propositions (testable in future work) about the possible nature and direction of knowledge flows in IURVs. We can anticipate that for a collaboration-driven IURV there will be a relatively equal bi-directional knowledge flow between partners. For a strategy-driven IURV, there could be knowledge flow from the host to the parent university, while the opposite direction will likely prevail for policy-driven and problem-driven IURVs. Moreover, for policy-driven IURVs, the intensity of knowledge flow might be expected to be relatively higher than for problem-driven IURVs because greater absorptive capacity in the host country.

We acknowledge that our data is collected for universities only from a single country - the United States with all the limitations following from our methods and sources of data collection. There is a clear need to be cautious in making causal interpretations. An obvious next step in our research is to collect and analyze worldwide-level data on IURV expansion to answer questions about the generalizability of our findings which are currently limited to U.S. university data. Another potential research direction is to turn attention from IURVs back to their parent universities to identify factors and strategies behind their participation or non-participation in the global trend of IURV establishment, which could inform decision-making on the topic of research internationalization by university researchers and administrators. Important questions also remain about the historical roots and evolution of the phenomenon, which might well be answered by early adoption case studies and quantitative time series analysis. All these studies could contribute to the integration of existing and developing models of IURVs and related phenomena in a general framework of university internationalization.

\section{Acknowledgements}

The research reported here is based upon work supported by the U.S. Army Research Laboratory and the U.S. Army Research Office through the Department of Defense Minerva Research Initiative under grant \#W911-NF- 15-1-0322. Sergey Kolesnikov worked on the project while at the School of Public Policy, Georgia Institute of Technology. We are grateful to Juan Rogers and Mark Zachary Taylor for helpful comments and to Jon Schmid and Olufunke Adebola for additional research assistance.

\section{References}

Allen, S. D., \& Link, A. N. (2015). US research joint ventures with international partners. International Entrepreneurship and Management Journal, 11(1), 169-181.

Altbach, P. G., \& Knight, J. (2007). The internationalization of higher education: Motivations and realities. Journal of studies in international education, 11(3-4), 290-305.

Bammer, G. (2008). Enhancing research collaborations: Three key management challenges. Research Policy, 37(5), 875-887.

Barjak, F., \& Robinson, S. (2007). International collaboration, mobility and team diversity in the life sciences: Impact on research performance. Social Geography Discussions, 3(1), 121-157.

Beaver, D. D. (2001). Reflections on scientific collaboration (and its study): past, present, and future. Scientometrics, 52(3), 365-377.

Berger, M., \& Hofer, R. (2011). The Internationalisation of Research and Technology Organisations (RTOs) Conceptual Notions and Illustrative Examples from European RTOs in China. Science, Technology and Society, 16(1), 99-122. 
Bonnema, A. B., Lin, Z., Qu, L., \& Jacobsen, E. (2006). Developing institutional collaboration between Wageningen university and the Chinese academy of agricultural sciences. NJAS-Wageningen Journal of Life Sciences, 53(3-4), 369-386.

Carnegie Foundation for the Advancement of Teaching (2011). The Carnegie Classification of Institutions of Higher Education, 2010 edition. http://carnegieclassifications.iu.edu/2010/.

CMU (2017a). Carnegie Mellon University Qatar, https://www.qatar.cmu.edu/.

CMU (2017b). Carnegie Mellon University Portugal Program, http://www.cmuportugal.org/.

CREATE (2017). Campus for Research Excellence and Technological Enterprise, Singapore. https://www.create.edu.sg/.

Corley, E. A., Boardman, P. C., \& Bozeman, B. (2006). Design and the management of multi-institutional research collaborations: Theoretical implications from two case studies. Research policy, 35(7), 975-993.

De Solla Price, D. J. (1963). Little Science, Big Science. New York: Columbia University Press.

Ebersberger, B., \& Edler, J. (2009). Internationalization of Public Research Organizations. Context, Strategies and Effects. The Atlanta Conference on Science and Innovation Policy October 2-3, 2009, Atlanta.

Engels, A., \& Ruschenburg, T. (2008). The uneven spread of global science: patterns of international collaboration in global environmental change research. Science and Public Policy, 35(5), 347-360.

Etzkowitz, H. (2003). MIT and the Rise of Entrepreneurial Science. Routledge.

Feng, Y. (2013). University of Nottingham Ningbo China and Xi'an Jiaotong-Liverpool University: globalization of higher education in China. Higher Education, 65(4), 471-485.

Friedman, T. L. (2005). The world is flat: A brief history of the twenty-first century. Macmillan.

Georgia Tech (2017). Georgia Tech - CNRS UMI 2958 Laboratory and Institut Lafayette. http://umi2958.gatech.edu/.

Georghiou, L. (1998). Global cooperation in research. Research policy, 27(6), 611-626.

Gibbons, M., Limoges, C., Nowotny, H., Schwartzman, S., Scott, P., \& Trow, M. (1994). The new production of knowledge: The dynamics of science and research in contemporary societies. Sage.

Guimon, J. (2016). Universities as multinational enterprises? The multinational university analyzed through the eclectic paradigm. Multinational Business Review, 24(3), 216-228. https://doi.org/10.1108/MBR-07-20160025

Guimón, J., Chaminade, C., \& Maggi, C. (2015). Policies to attract R\&D-related FDI in Chile: Aligning incentives with local linkages and absorptive capacities (No. 2015/48). Lund University, CIRCLE-Center for Innovation, Research and Competences in the Learning Economy.

Hird, M. D., \& Pfotenhauer, S. M. (2017). How complex international partnerships shape domestic research clusters: Difference-in-difference network formation and research re-orientation in the MIT Portugal Program. Research Policy, 46(3), 557-572.

Jones, B. F., Wuchty, S., \& Uzzi, B. (2008). Multi-university research teams: Shifting impact, geography, and stratification in science. Science, 322(5905), 1259-1262.

Jonkers, K. (2009). Emerging ties: Factors underlying China's co-publication patterns with Western European and North American research systems in three molecular life science subfields. Scientometrics, 80(3), 775-795.

Jonkers, K., \& Cruz-Castro, L. (2010). The internationalisation of public sector research through international joint laboratories. Science and Public Policy, 37(8), 559.

Katz, J. S., \& Martin, B. R. (1997). What is research collaboration?. Research policy, 26(1), 1-18.

Kinser, K., \& Lane, J. (2015). Foreign outposts of colleges and universities. International Higher Education, 66, 23.

Kinser, K., \& Lane, J. (2016). International Branch Campuses: Evolution of a Phenomenon. International Higher Education, 85, 3-5.

Klerkx, L., \& Guimón, J. (2017). Attracting foreign R\&D through international centres of excellence: early experiences from Chile. Science and Public Policy, https://doi.org/10.1093/scipol/scx011

Knight, J. (2004). Internationalization remodeled: Definition, approaches, and rationales. Journal of studies in international education, 8(1), 5-31.

Krige, J. (2015). Regulating the Academic "Marketplace of Ideas": Commercialization, Export Controls, and Counterintelligence. Engaging Science, Technology, and Society, 1, 1-24.

Kuemmerle, W. (1999). The drivers of foreign direct investment into research and development: an empirical investigation. Journal of international business studies, 30(1), 1-24.

Lane, J. E. (2011). Global expansion of international branch campuses: Managerial and leadership challenges. New Directions for Higher Education, 2011 (155), 5-17. 
Laredo, P. (2007). Revisiting the third mission of universities: Toward a renewed categorization of university activities? Higher education policy, 20(4), 441-456.

Lee, S., \& Bozeman, B. (2005). The impact of research collaboration on scientific productivity. Social studies of science, 35(5), 673-702.

Li, J. (2010). Global R\&D alliances in China: Collaborations with universities and research institutes. IEEE Transactions on Engineering Management, 57(1), 78-87.

Link, A. N., \& Scott, J. T. (2005). Universities as partners in US research joint ventures. Research Policy, 34(3), 385-393.

Melin, G. (2000). Pragmatism and self-organization: Research collaboration on the individual level. Research policy, 29(1), 31-40.

Morillo, F., Bordons, M., \& Gómez, I. (2003). Interdisciplinarity in science: A tentative typology of disciplines and research areas. Journal of the American Society for Information Science and technology, 54(13), 12371249.

National Science Board (2016). Science and Engineering Indicators. Arlington, VA: National Science Foundation (NSB-2016-1).

OECD (1997). Revised Field of Science and Technology (FOS) classification in the Frascati Manual, retrieved from http://www.oecd.org/science/inno/38235147.pdf.

Olds, K. (2007). Global assemblage: Singapore, foreign universities, and the construction of a "global education hub". World development, 35(6), 959-975.

Peters, M. A. (2006). The Rise of Global Science and the Emerging Political Economy of International Research Collaborations1. European Journal of Education, 41(2), 225-244.

Pfotenhauer, S. M., Jacobs, J. S., Pertuze, J. A., Newman, D. J., \& Roos, D. T. (2013). Seeding change through international university partnerships: the MIT-Portugal program as a driver of internationalization, networking, and innovation. Higher Education Policy, 26(2), 217-242.

Pfotenhauer, S. M., Wood, D., Roos, D., \& Newman, D. (2016). Architecting complex international science, technology and innovation partnerships (CISTIPs): A study of four global MIT collaborations. Technological Forecasting and Social Change, 104, 38-56.

Schmid, J., Kolesnikov, S. A., \& Youtie, J. (2017). Plans versus experiences in transitioning transnational education into research and economic development: a case study. Science and Public Policy, https://doi.org/10.1093/scipol/scx051

Scott, J. C. (2006). The mission of the university: Medieval to postmodern transformations. The journal of higher education, 77(1), 1-39.

Shams, F., \& Huisman, J. (2016). The role of institutional dual embeddedness in the strategic local adaptation of international branch campuses: Evidence from Malaysia and Singapore. Studies in Higher Education, 41(6), 955-970.

Sidhu, R. (2009a). The 'brand name'research university goes global. Higher Education, 57(2), 125-140.

Sidhu, R. (2009b). Running to stay still in the knowledge economy. Journal of Education Policy, 24(3), 237-253.

Sidhu, R., Ho, K. C., \& Yeoh, B. S. (2014). Singapore: Building a knowledge and education hub. In International Education Hubs (pp. 121-143). Springer Netherlands.

Skolnikoff, E. B. (1994). The elusive transformation: science, technology, and the evolution of international politics. Princeton University Press.

Thursby, J. G., \& Thursby, M. C. (2006). Here or There? a survey of factors in multinational R\&D location: report to the Government/University/Industry research roundtable.

United Nations Development Programme. (2015). Human development report 2015: Work for human development. Retrieved from http://hdr.undp.org/sites/default/files/2015_human_development_report.pdf

United Nations. (2015). Transforming our world: the 2030 Agenda for Sustainable Development. General Assembly Resolution A/RES/70/1, 25 September 2015, retrieved from http://www.un.org/ga/search/view_doc.asp?symbol=A/RES/70/1\&Lang=E

Von Zedtwitz, M., \& Gassmann, O. (2002). Market versus technology drive in R\&D internationalization: four different patterns of managing research and development. Research policy, 31(4), 569-588.

Vonortas, N. S. (1997). Research joint ventures in the US. Research Policy, 26(4), 577-595.

Wagner, C. S., Brahmakulam, I., Jackson, B., Wong, A., \& Yoda, T. (2001). Science and technology collaboration: Building capability in developing countries (No. RAND/MR-1357.0-WB). RAND Corporation, Santa Monica, CA.

Wagner, C. S., \& Leydesdorff, L. (2005). Network structure, self-organization, and the growth of international collaboration in science. Research policy, 34(10), 1608-1618. 
Wagner, C. S., Park, H. W., \& Leydesdorff, L. (2015). The continuing growth of global cooperation networks in research: A conundrum for national governments. PLoS One, 10(7), e0131816.

Walsh, J. P., \& Lee, Y. N. (2015). The bureaucratization of science. Research Policy, 44(8), 1584-1600.

Wilkins, S., \& Huisman, J. (2012). The international branch campus as transnational strategy in higher education. Higher Education, 64(5), 627-645.

Wuchty, S., Jones, B. F., \& Uzzi, B. (2007). The increasing dominance of teams in production of knowledge. Science, 316(5827), 1036-1039.

Yale University (2017). Fudan-Yale Biomedical Research Center in China, http://world.yale.edu/china-researchcenters.

Youtie, J., Libaers, D., \& Bozeman, B. (2006). Institutionalization of university research centers: the case of the National Cooperative Program in Infertility Research. Technovation, 26(9), 1055-1063.

Youtie, J., \& Shapira, P. (2008). Building an innovation hub: A case study of the transformation of university roles in regional technological and economic development. Research policy, 37(8), 1188-1204.

Youtie, J., Li, Y., Rogers, J., \& Shapira, P. (2017). Institutionalization of international university research ventures. Research Policy, 46(9), 1692-1705.

Zacharewicz, T., Sanz Menendez, L., Jonkers, K. (2017), The Internationalisation of Research and Technology Organisations, EUR 28442 EN, doi:10.2760/944413

Zhang, H., Patton, D., \& Kenney, M. (2013). Building global-class universities: Assessing the impact of the 985 Project. Research Policy, 42(3), 765-775.

Zitt, M., Bassecoulard, E., \& Okubo, Y. (2000). Shadows of the past in international cooperation: Collaboration profiles of the top five producers of science. Scientometrics, 47(3), 627-657. 


\section{Appendix}

List of US Research Universities with Identified International University Research Ventures (IURVs)

\begin{tabular}{|c|c|c|}
\hline UNIVERSITY & IURVs & $\begin{array}{l}\text { Number } \\
\text { of IURVs }\end{array}$ \\
\hline $\begin{array}{l}\text { Massachusetts } \\
\text { Institute of } \\
\text { Technology }\end{array}$ & $\begin{array}{l}\text { MIT-Skoltech Program, Singapore - MIT Alliance for Research and } \\
\text { Technology Centre (SMART), MIT-Portugal Program, Tsinghua-MIT- } \\
\text { CUHK Research Center for Theoretical Computer Science, Masdar Institute } \\
\text { of Science and Technology, Center for Complex Engineering Systems, } \\
\text { CSAIL \& QCRI Computer Science Research Program, MIT-UTM Malaysia } \\
\text { Sustainable Cities Program, Malaysia Institute for Supply Chain Innovation, } \\
\text { Zaragoza Logistics Center (ZLC), Center for Latin-American Logistics } \\
\text { Innovation, Tsinghua-MIT China Energy \& Climate Project, Singapore } \\
\text { University of Technology and Design, Madrid-MIT M+Visión Consortium }{ }^{\mathrm{a}} \text {, } \\
\text { HKUST-MIT Research Alliance Consortium, Cambridge-MIT Institute } \\
\text { (CMI) }^{\mathrm{a}} \text {, Media Lab Europe }{ }^{\mathrm{a}} \text {, Media Lab Asia }{ }^{\mathrm{a}} \text {, Malaysia University of } \\
\text { Science \& Technology }{ }^{\mathrm{a}} \text {, Centro de Innovación Tecnológica (CIT) } \\
\text { AUB/MIT Collaborative Program in Science, Technology, and } \\
\text { Development }{ }^{\mathrm{a}} \text {, Development Research and Technological Planning Center } \\
\text { (DRTPC) }^{\mathrm{a}}, \text { Luxembourg Centre for Logistics and Supply Chain }^{\mathrm{a}} \text { Management }{ }^{\mathrm{a}} \text {, Ningbo Supply Chain Innovation Institute China (NCIIC) }\end{array}$ & 24 \\
\hline $\begin{array}{l}\text { University of } \\
\text { Michigan-Ann } \\
\text { Arbor }\end{array}$ & $\begin{array}{l}\text { Joint Institute for Translational and Clinical Research, UM/Israel Partnership } \\
\text { for Research, UM-SJTU Joint Institute, Tsinghua-Michigan Joint Center for } \\
\text { Quantum Information, CIRHT Ethiopia, Ethiopia-Michigan Platform for } \\
\text { Advancing Collaborative Engagement (EM-PACE), Pantanal Center for } \\
\text { Education and Research (PCER), UMich-FIOCRUZ Collaboration, } \\
\text { International Center for Advanced Research and Training (ICART), Social } \\
\text { and Economic Survey Research Institute (SESRI), Petroleum and } \\
\text { Petrochemical College at Chulalongkorn University }\end{array}$ & 11 \\
\hline $\begin{array}{c}\text { Georgia Institute of } \\
\text { Technology }\end{array}$ & $\begin{array}{l}\text { Georgia Tech-Lorraine (GTL) (including GT-CNRS UMI), The Logistics } \\
\text { Institute Asia Pacific, Costa Rica Trade Innovation \& Productivity Center, } \\
\text { The Georgia Tech Panama Logistics Innovation and Research Center, The } \\
\text { Trade \& Logistics Innovation Center of Mexico, Sino-US Global Logistics } \\
\text { Institute (SUGLI), Sino-U.S. Eco Urban Lab, GT/Emory - PKU BME Joint } \\
\text { Venture, Georgia Tech-Ireland }\end{array}$ & 9 \\
\hline Yale University & $\begin{array}{l}\text { Yale UCL Collaborative, Fudan-Yale Biomedical Research Center, SJTU- } \\
\text { Yale Joint Center for Biostatistics, Peking-Yale Joint Center for } \\
\text { Microelectronics and Nanotechnology, Peking-Yale Joint Center for Plant } \\
\text { Molecular Genetics and Agrobiotechnology, Yale NUS College, USTC-Yale } \\
\text { Joint Research Center for High-Confidence Software (HCS), Yale- } \\
\text { Universidad de Chile Joint Program in Astronomy, International Training } \\
\text { Center for Global Infectious Disease Research }\end{array}$ & 9 \\
\hline $\begin{array}{l}\text { Arizona State } \\
\text { University }\end{array}$ & $\begin{array}{l}\text { Arizona State University (ASU)/Dublin City University (DCU) Transatlantic } \\
\text { Higher Education Partnership, Center for Global Sustainability and Cultural } \\
\text { Transformation (Germany), Binational Laboratory on Smart Sustainable } \\
\text { Energy Management and Technology Training (Mexico), Energy Decision } \\
\text { Center for Mexico, Biodesign Center China, Biosignatures Center (Taiwan), } \\
\text { University Design Consortium, U.S.-Pakistan Center for Advanced Studies } \\
\text { in Energy (USPCAS-E) }\end{array}$ & 8 \\
\hline $\begin{array}{l}\text { Johns Hopkins } \\
\text { University }\end{array}$ & $\begin{array}{l}\text { SAIS Europe, Johns Hopkins Singapore, Joint Transatlantic Research and } \\
\text { Policy Center, JHU-SYSU Collaboration, Trinidad and Tobago Health } \\
\text { Sciences Initiative }{ }^{\text {a }} \text {, Johns Hopkins University Public Policy Center, Johns } \\
\text { Hopkins University in Malaysia - Perdana University Graduate School of } \\
\text { Medicine }^{c}\end{array}$ & 7 \\
\hline
\end{tabular}




\begin{tabular}{|c|c|c|}
\hline $\begin{array}{l}\text { Carnegie Mellon } \\
\text { University }\end{array}$ & $\begin{array}{l}\text { SYSU-CMU Joint Institute of Engineering (JIE), SYSU-CMU Shunde } \\
\text { International Joint Research Institute, Carnegie Mellon University Qatar, } \\
\text { Carnegie Mellon University Australia, Madeira Interactive Technologies } \\
\text { Institute (Madeira-ITI), Carnegie Mellon Portugal Program }\end{array}$ & 6 \\
\hline Harvard University & $\begin{array}{l}\text { Catholic-Harvard Wellman Center for Photomedicine, Sogang-Harvard } \\
\text { Disease Biophysics Research Center, Harvard Medical School Center for } \\
\text { Global Health Delivery-Dubai, Harvard Medical School Dubai Center } \\
\text { (HMSDC) }^{\text {a }} \text { Botswana-Harvard Partnership (BHP), Africa Academy for } \\
\text { Public Health (AAPH) }\end{array}$ & 6 \\
\hline Stanford University & $\begin{array}{l}\text { Global Station for Quantum Medical Science and Engineering, Singapore- } \\
\text { Stanford Biodesign Programme, Stanford-India Biodesign }{ }^{\mathrm{a}} \text {, Japan Biodesign } \\
\text { Program, Singapore Stanford Partnership (SSP) }{ }^{\mathrm{a}} \text {, Bioinnovate Ireland }\end{array}$ & 6 \\
\hline $\begin{array}{l}\text { University of } \\
\text { Pennsylvania }\end{array}$ & $\begin{array}{l}\text { Botswana-UPenn Partnership, IBPCAS-Penn Joint Center of Excellence in } \\
\text { Brain Mapping, PKU-University of Pennsylvania Center of Excellence in } \\
\text { Sleep Medicine, Guatemala-Penn Partnership, Penn/HKUST Collaborative } \\
\text { Research Alliance, SJTU-Penn Center of Excellence in Medical Imaging }\end{array}$ & 6 \\
\hline $\begin{array}{l}\text { Pennsylvania State } \\
\text { University }\end{array}$ & $\begin{array}{l}\text { AfricaArray, Joint Root Biology Lab, Joint Center for Energy Research } \\
\text { (JCER), Penn State/NM-AIST Tanzania EcoHealth Partnership, 2iE - Penn } \\
\text { State Centre for Collaborative Engagement }\end{array}$ & 5 \\
\hline $\begin{array}{l}\text { University of } \\
\text { California-Berkeley }\end{array}$ & $\begin{array}{l}\text { Tsinghua-UC Berkeley Shenzhen Institute (TBSI), Berkeley Education } \\
\text { Alliance for Research in Singapore, Shanghai Zhangjiang Berkeley } \\
\text { Engineering Innovation Center (Z-BEI), Berkeley Tsinghua Joint Research } \\
\text { Center on Energy and Climate Change }{ }^{\text {b }} \text { International Joint Research } \\
\text { Laboratory of Earthquake Engineering (ILEE) }\end{array}$ & 5 \\
\hline $\begin{array}{l}\text { University of } \\
\text { California-Davis }\end{array}$ & $\begin{array}{l}\text { Sino-U.S. Joint Research Center for Food Safety, UC Davis Chile - Life } \\
\text { Sciences Innovation Center, Horticulture Innovation Lab Regional Center at } \\
\text { Kasetsart University, Horticulture Innovation Lab Regional Center at } \\
\text { Zamorano, U.S.-Pakistan Centers for Advanced Studies in Agriculture and } \\
\text { Food Security (USPCAS-AFS) }\end{array}$ & 5 \\
\hline Princeton University & $\begin{array}{l}\text { Collaborative Innovation Center for Advanced Fusion Energy and Plasma } \\
\text { Sciences (CICAFEPS), NAOJ-Princeton Astrophysics Collaboration (N- } \\
\text { PAC), Max-Planck Princeton Center for Fusion and Astro Plasma Physics, } \\
\text { Oxford-Princeton Research Partnership }\end{array}$ & 4 \\
\hline $\begin{array}{l}\text { Texas A \& M } \\
\text { University }\end{array}$ & $\begin{array}{l}\text { Texas A\&M University at Qatar, Texas A \& M University in Israel }{ }^{\mathrm{b}} \text {, Soltis } \\
\text { Center for Research and Education, Gulf Nuclear Energy Infrastructure } \\
\text { Institute }\end{array}$ & 4 \\
\hline $\begin{array}{l}\text { University of } \\
\text { Alabama at } \\
\text { Birmingham }\end{array}$ & $\begin{array}{l}\text { UAB-South Asia International Training and Research in Environmental and } \\
\text { Occupational Health (ITREOH) in Pakistan, UAB-South Asia ITREOH in } \\
\text { India, UAB-South Asia ITREOH in Sri Lanka, Centre for Infectious Disease } \\
\text { Research in Zambia (CIDRZ) }\end{array}$ & 4 \\
\hline $\begin{array}{l}\text { University of } \\
\text { Chicago }\end{array}$ & $\begin{array}{l}\text { The University of Chicago Center in Beijing, The University of Chicago } \\
\text { Center in Delhi, The University of Chicago Center in Paris, The University } \\
\text { of Chicago Research Bangladesh }\end{array}$ & 4 \\
\hline $\begin{array}{l}\text { University of North } \\
\text { Carolina at Chapel } \\
\text { Hill }\end{array}$ & $\begin{array}{l}\text { Galapagos Science Center, UNC-PKU Consortium for Urban and Regional } \\
\text { Planning and Management, UNC-Project Malawi, UNC-Tsinghua Center for } \\
\text { Logistics and Enterprise Development }\end{array}$ & 4 \\
\hline $\begin{array}{l}\text { University of } \\
\text { Southern California }\end{array}$ & $\begin{array}{l}\text { Korean Air / General Electric Research Institute for International } \\
\text { Collaboration (KAGERIIC), Joint Institute for Mobile Innovations (JIMI), } \\
\text { Airbus Institute for Engineering Research (AIER), Pratt \& Whitney Institute } \\
\text { for Collaborative Engineering (PWICE) }\end{array}$ & 4 \\
\hline Duke University & $\begin{array}{l}\text { Duke-Kunshan University, Duke-NUS Graduate Medical School, Medanta } \\
\text { Duke Research Institute (MDRI) }\end{array}$ & 3 \\
\hline $\begin{array}{l}\text { Michigan State } \\
\text { University }\end{array}$ & $\begin{array}{l}\text { Sun Yat-Sen University - Michigan State University Joint Center of Vector } \\
\text { Control for Tropical Disease, Innovation Hub (Malawi), Tanzania } \\
\text { Partnership Program (TPP) }\end{array}$ & 3 \\
\hline
\end{tabular}




\begin{tabular}{|c|c|c|}
\hline $\begin{array}{l}\text { University of New } \\
\text { Mexico-Main } \\
\text { Campus }\end{array}$ & $\begin{array}{l}\text { UNM/KEMRI in Kisumu - Kenya, UNM/KEMRI in Siaya - Kenya, } \\
\text { UNM/KEMRI/Ogra Pediatric Research Centre }\end{array}$ & 3 \\
\hline $\begin{array}{l}\text { Virginia Polytechnic } \\
\text { Institute and State } \\
\text { University }\end{array}$ & $\begin{array}{l}\text { ERA Senegal, The Caribbean Center for Education and Research, Virginia } \\
\text { Tech - India ICTAS Innovation Center }\end{array}$ & 3 \\
\hline $\begin{array}{l}\text { California Institute } \\
\text { of Technology }\end{array}$ & $\begin{array}{l}\text { Caltech-Taiwan Energy Exchange (CTEE) }{ }^{\mathrm{a}} \text {, Shimojo-TUT International } \\
\text { Collaborative Research Laboratory }\end{array}$ & 2 \\
\hline $\begin{array}{l}\text { Colorado State } \\
\text { University }\end{array}$ & $\begin{array}{l}\text { Russian State Agrarian University Partnership }{ }^{\text {a }} \text {, Joint International Rural } \\
\text { Institute (JIRI) }\end{array}$ & 2 \\
\hline $\begin{array}{l}\text { Columbia } \\
\text { University in the } \\
\text { City of New York }\end{array}$ & Rio Innovation Hub, The MDG Centre & 2 \\
\hline Cornell University & $\begin{array}{l}\text { NAU-Cornell International Technology Transfer Center, Weill Cornell } \\
\text { Medical College in Qatar's (WCMC-Q) }\end{array}$ & 2 \\
\hline $\begin{array}{l}\text { New York } \\
\text { University }\end{array}$ & NYU Abu Dhabi, NYU Shanghai & 2 \\
\hline $\begin{array}{l}\text { Northwestern } \\
\text { University }\end{array}$ & $\begin{array}{l}\text { Sino-America Joint Institute for Engineering Design and Simulations(IEDS), } \\
\text { Northwestern University in Qatar }\end{array}$ & 2 \\
\hline $\begin{array}{l}\text { Stony Brook } \\
\text { University }\end{array}$ & SUNY Korea, CEWIT Korea & 2 \\
\hline $\begin{array}{l}\text { University at } \\
\text { Buffalo }\end{array}$ & $\begin{array}{l}\text { Zimbabwe International Nanotechnology Center, Buffalo Jamaica } \\
\text { Innovation Enterprise }\end{array}$ & 2 \\
\hline $\begin{array}{l}\text { University of } \\
\text { California-Los } \\
\text { Angeles }\end{array}$ & PKU-UCLA Joint Research Institute, Congo Basin Institute & 2 \\
\hline $\begin{array}{l}\text { University of } \\
\text { California-San } \\
\text { Diego }\end{array}$ & $\begin{array}{l}\text { University of California San Diego - Ethiopia (UCSD-E), Perdana } \\
\text { University Graduate School of Medicine }\end{array}$ & 2 \\
\hline $\begin{array}{l}\text { University of } \\
\text { Illinois at Chicago }\end{array}$ & $\begin{array}{l}\text { Global Environmental and Occupational Health Research Hub (GEOHub), } \\
\text { Louise Hamilton Kyiv Center of Excellence for Environmental and } \\
\text { Occupational Health }\end{array}$ & 2 \\
\hline University of Utah & $\begin{array}{l}\text { Utah-Inha Joint Research Center on Drug Delivery Systems \& Advanced } \\
\text { Therapeutics, U.S.- Pakistan Center for Advanced Studies in Water } \\
\text { (USPCAS-W) }\end{array}$ & 2 \\
\hline Boston University & Boston University Institute of Dental Research and Education Dubai ${ }^{\mathrm{a}}$ & 1 \\
\hline Dartmouth College & Tuberculosis Research Institute at MUHAS (TRIM-TB) & 1 \\
\hline Emory University & GT/Emory - PKU BME Joint Venture & 1 \\
\hline $\begin{array}{l}\text { Georgetown } \\
\text { University }\end{array}$ & Georgetown University School of Foreign Service in Qatar (SFS-Q) & 1 \\
\hline $\begin{array}{l}\text { Indiana University- } \\
\text { Bloomington }\end{array}$ & Academic Model for Providing Access to Healthcare (AMPATH) & 1 \\
\hline Purdue University & The India-US Joint Networked Centre on Nanomaterials & 1 \\
\hline $\begin{array}{l}\text { The University of } \\
\text { Tennessee }\end{array}$ & China-US Joint Research Center for Ecosystem and Environmental Change & 1 \\
\hline $\begin{array}{l}\text { The University of } \\
\text { Texas at Austin }\end{array}$ & UT Austin Portugal & 1 \\
\hline $\begin{array}{l}\text { University of } \\
\text { Connecticut }\end{array}$ & Ethiopian Institute of Water Resources (EIWR) & 1 \\
\hline $\begin{array}{c}\text { University of } \\
\text { Delaware }\end{array}$ & Joint Institute for Coastal Research and Management & 1 \\
\hline $\begin{array}{l}\text { University of } \\
\text { Florida }\end{array}$ & Haiti Public Health Laboratory & 1 \\
\hline
\end{tabular}




\begin{tabular}{|c|c|c|}
\hline $\begin{array}{c}\text { University of } \\
\text { Illinois at Urbana- } \\
\text { Champaign }\end{array}$ & Advanced Digital Sciences Center (ADSC) & 1 \\
\hline $\begin{array}{c}\text { University of } \\
\text { Missouri-Columbia }\end{array}$ & FAPRI-Ireland Partnership & 1 \\
\hline $\begin{array}{c}\text { University of } \\
\text { Oklahoma Norman } \\
\text { Campus }\end{array}$ & Petroleum and Petrochemical College at Chulalongkorn University & 1 \\
\hline $\begin{array}{l}\text { University of } \\
\text { Oregon }\end{array}$ & Gabon-Oregon Center & 1 \\
\hline $\begin{array}{l}\text { University of } \\
\text { Rochester }\end{array}$ & $\begin{array}{l}\text { Sino-American Cone Beam Volume CT Research Center of Image } \\
\text { Engineering }\end{array}$ & 1 \\
\hline $\begin{array}{l}\text { University of } \\
\text { Georgia }\end{array}$ & UGA Costa Rica & 1 \\
\hline $\begin{array}{c}\text { Virginia } \\
\text { Commonwealth } \\
\text { University }\end{array}$ & VCUQatar & 1 \\
\hline $\begin{array}{c}\text { Case Western } \\
\text { Reserve University }\end{array}$ & Petroleum and Petrochemical College at Chulalongkorn University & 1 \\
\hline
\end{tabular}

${ }^{a}$ Ceased operation or became independent

${ }^{\mathrm{b}}$ In planning or development stage by Summer 2016

${ }^{\mathrm{c}}$ Ownership transferred to another U.S. university 